\title{
Crop diversification with and without irrigation: Selected tribal households of South Odisha
}

\author{
Sadasiba Tripathy*and Dr. Sandhyarani Das \\ Berhampur University, Berhampur-760007, Odisha, India
}

\begin{abstract}
This paper aims to analyze the impact of irrigation on crop diversification. Crop diversification index has been employed to study the nature and extent of crop diversification in the study area. Descriptive statistics is used to explain the average CDI and irrigation. We found a mixed correlation between the factors and also observed a fluctuate impact on the crop diversification in the study area.
\end{abstract}

Key words - Crop diversification, Irrigation, Tribal households

JEL codes- Q10, Q15

\section{Introduction}

Crop diversification means changing the cropping pattern from the production of traditional crops to the cash crops. It is the process to cultivate non-paddy crops from paddy. We can also say that crop diversification means production of high value crops from the low value crops [1]. Farmers get a better income due to crop diversification [2]. The increased demand and price for the vegetables also lead to crop diversification [3]. There are different factors like rain-fall, fertilizer, irrigation, farmer's knowledge etc are responsible for crop diversification in the study area [4] but sometimes due the climate change and unproductive rain there is crop concentration rather than diversification [5].

Objective of this study is as follows:

- To study the nature and extent of crop diversification in the study area.

- To analyze the impact of irrigation potential on crop diversification

- To suggest some polices to improve the present agricultural practices in the study area.

\section{Analysis Technique}

\subsection{Methodology}

We have taken both primary and secondary data. As primary data, we have employed purposive sampling to choose the village where more than $60 \%$ of the inhabitants are tribals and used simple random sampling to survey the sample household. The sample households were interviewed in order to deduce the inferences. As secondary data we have taken the demographic features from the census of India, 2011 [7].

\footnotetext{
*tripathy.sadasiba@gmail.com
} 


\subsection{Selection of the model}

We have employed crop diversification index and simple linear regression. Crop diversification index (CDI) by Gibbs and Martin's techniques [8] is given by:

$$
\mathrm{CDI}=\frac{\sum \mathrm{X}^{2}}{\left(\sum \mathrm{X}\right)^{2}}
$$

Simple linear regression expression may be written as: $\mathrm{Y}=\mathrm{b}_{0}+\mathrm{b}_{1} \mathrm{X}_{1}+\varepsilon$

Where, $\mathrm{Y}=$ crop diversification (dependent variable),

$\mathrm{b}_{0}=$ estimate of the regression intercept,

$\mathrm{b}_{1}=$ estimate of the regression slope,

$\mathrm{X}_{1}=$ irrigation (Independent variable),

and $\varepsilon$ is error term

\subsection{Explanation of the variables:}

Crop diversification:

Here we have taken crop diversification index as the dependent variable. Crop diversification is always an important measure to raise the standard of living and raises the effective demand in the economy. In calculating CDI we have taken into account the diversified crop not the paddy crop.

Irrigation:

Irrigation is the most important factor which supports cultivation to all the crops may be paddy or non-paddy. So the growth of the agricultural activities always dependent on irrigation potential of the said area.

\section{Profile of the Study Area}

\subsection{Gadaba tribe}

Gadaba is the dominating tribe in both the villages. They have some distinct features of way of life. In Odisha, the tribe is found in 8 districts, Viz. Koraput, Malkangiri, Nabarangapur, Rayagada, Kalahandi, Sundargarh, Khordha, and Nayagarh. In Koraput district the tribe has the highest population. In this village, the effect of the modern life can be observed with the changing life style of the tribe [6].

\subsection{Demographic profile}

We have taken Sindhigam and Putra for our study. In Tab. 1 it can be seen that the total number of households in the 2 villages is 382 and the average household is 191. Similarly the total population of the study area is 1804 and the average population per village is 902 and per household is 4.72. Out of which, the child population belongs to the age group of 0-6 is 315 which is $17.46 \%$ of the total population.

The total number of schedule caste population is 100 is $5.54 \%$ of total population and the total population of schedule tribe is 1133 which is $62.8 \%$ of total population. The rest $31.66 \%$ belongs to other caste. The average literacy of these 2 villages is $50.88 \%$. If you will observe the literacy of the villages individually you can see, the highest literacy is found in Putra village i.e. $51.94 \%$ and comparatively lower i.e. $49.83 \%$ in Sindhigam.

\subsection{Work profile}

The Tab. 2 shows the wok profile of the study area. The total workers of the study area are 840 which is $46.56 \%$ of the total population. So we can say that the number of productive population 
Table 1: Demographic profile as per 2011 census [7]

\begin{tabular}{c|c|c}
\hline Particulars & Sindhigam & Putra \\
\hline No. of families & 86 & 296 \\
\hline Total family members & 366 & 1438 \\
\hline Child (0-6 age) & 63 & 252 \\
\hline Schedule Tribe & 294 & 839 \\
\hline Schedule Caste & 33 & 67 \\
\hline Literacy (in \%) & 49.83 & 51.94 \\
\hline
\end{tabular}

is comparatively lower than dependent population. Coming to the total number of main and marginal workers, they are 702 and 138 respectively.

Table 2: Work profile as per 2011 census [7]

\begin{tabular}{c|c|c}
\hline Particulars & Sindhigam & Putra \\
\hline Total Workers & 216 & 624 \\
\hline Main Worker & 117 & 585 \\
\hline Marginal Worker & 99 & 39 \\
\hline
\end{tabular}

In percentage, the main workers are $83.57 \%$ of the total workforce and $38.91 \%$ of the total population of the study area. Similarly in case of marginal workers, they are $16.42 \%$ of the total workforce and $7.64 \%$ of the total population. The concept of the main workers are those who get employment more than 6 month a year and the marginal workers get the employment less than 6 months a years as described by them. In this regard we can say that the main workers are outnumbered than the marginal workers.

\section{Results and discussion}

\subsection{Diversification of crops}

In Sindhigam we can observe that the farmers started the process of crop diversification since the year 2008-09 which can be observe the area under crops from Tab. 3. Gradually they have changing their cropping pattern. In 2008-09 the percentage of area under diversified crops is $17.04 \%$ and $19.54 \%$ in $2013-14$ which again rose to $69.46 \%$ in $2018-19$. Similarly In Putra we can observe that the farmers started the process of crop diversification since the year 2012-13 and we can observe the area under crops. In 2013-14 the percentage of area under diversified crops is $17.48 \%$ which rose to $47.96 \%$ in $2018-19$.

\subsection{Irrigated areas}

Coming to the irrigation potential we can see the Govt. is taking step to raise the irrigation potential in the village and gradually it has been increased. The range of the irrigation potential is within 40 to 60 percent of the surveyed land. It can be seen in Tab. 4.

This table shows the agricultural land covered by the irrigation facilities of the surveyed sample households.

\subsection{Regression and Descriptive Statistics}

In Tab. 5 there are the results of descriptive statistics and in Tab. 6 we have analyzed the econometric results i.e. regression analysis. Here there are 3 tome periods 2008-09, 2013-14 and 
Table 3: area under crops [9]

\begin{tabular}{c|c|c|c|c}
\hline Village & Crops & $2008-09$ & $2013-14$ & $2018-19$ \\
\hline Sindhigam & Paddy & 82.96 & 80.46 & 30.54 \\
\cline { 2 - 5 } & Cowpea & 6.73 & 5 & 15.57 \\
\cline { 2 - 5 } & Ridge gourd & 4.76 & 3.21 & 20.36 \\
\cline { 2 - 5 } & Bean & 0 & 5.71 & 7.18 \\
\cline { 2 - 5 } & tomato & 1.34 & 2.5 & 11.38 \\
\cline { 2 - 5 } & Brinjal & 4.21 & 3.12 & 14.97 \\
\hline \hline Putra & Paddy & 100 & 85.52 & 52.04 \\
\cline { 2 - 5 } & Spiny gourd & 0 & 0 & 13.48 \\
\cline { 2 - 5 } & Pointed gourd & 0 & 2.51 & 6.90 \\
\cline { 2 - 5 } & Coccinia & 0 & 4.39 & 8.78 \\
\cline { 2 - 5 } & Brinjal & 0 & 4.39 & 3.49 \\
\cline { 2 - 5 } & Cowpea & 0 & 3.45 & 5.33 \\
\cline { 2 - 5 } & Sugarcane & 0 & 2.74 & 10.03
\end{tabular}

Table 4: Irrigation area in percentage

\begin{tabular}{|c|c|c|c|}
\hline Name of the villages/year & 2008-091 & 2013-14 & $2018-19$ \\
\hline Sindhigam & 12.31 & 22.64 & 41.92 \\
\hline Putra & 26.7 & 35.8 & 56.32 \\
\hline
\end{tabular}

2018-19. In Tab. 5 we can there is regress growth in the rate of crop diversification in Sindhigam and same in case of Putra.

Table 5: Descriptive Statistics

\begin{tabular}{c|c|c|c} 
Variables & Year & Sindhigam & Putra \\
\hline \multirow{4}{*}{ CDI(Y) } & $2008-09$ & 0.3 & 0. \\
\cline { 2 - 4 } & $2013-14$ & 0.22 & 0.26 \\
\cline { 2 - 4 } & $2018-19$ & 0.22 & 0.24 \\
\cline { 2 - 4 } & Mean CDI & 0.25 & 0.17 \\
\cline { 2 - 4 } & SD of CDI & 0.038 & 0.12 \\
\hline \hline Irrigation (X) & $2008-09$ & 12.31 & 26.7 \\
\cline { 2 - 4 } & $2013-14$ & 22.64 & 35.8 \\
\cline { 2 - 4 } & $2018-19$ & 41.92 & 56.32 \\
\cline { 2 - 4 } & Mean Irrigation & 25.62 & 39.61 \\
\cline { 2 - 4 } & SD of Irrigation & 12.27 & 12.39
\end{tabular}

Coming to irrigation potential, it is higher in Putra than in Sindhigam. In 2018-19 56.32\% of the surveyed land is irrigated in Putra and in Sindhigam it is $41.92 \%$.

Table 6: Coefficient Of correlation results

\begin{tabular}{c|c|c}
\hline Coefficient Of correlation & Sindhigam & Putra \\
\hline $\mathrm{r}$ & -0.76 & 0.69
\end{tabular}

The Pearson's coefficient of correlation between crop diversification and irrigation has a negative correlation that is -0.76 in Sindhigam but in Putra that is positive at 0.69 .

By taking CDI as dependent variable $(\mathrm{Y})$ and irrigation as independent variable $(\mathrm{X})$, we have calculated SLR to analyze the cause and effect relationship between two variables. The values 
Table 7: Simple linear Regression Equation

\begin{tabular}{c|c|c|c}
\hline Village name & $\mathrm{b} 0$ & $\mathrm{~b} 1$ & $\mathrm{Y}=\mathrm{b}_{0}+\mathrm{b}_{1} \times \mathrm{X}$ \\
\hline Sindhigam & 0.31 & -0.0023 & $\mathrm{Y}=0.31-0.0023 \times \mathrm{X}$ \\
\hline Putra & -0.093 & 0.0066 & $\mathrm{Y}=-0.093+0.0066 \times \mathrm{X}$
\end{tabular}

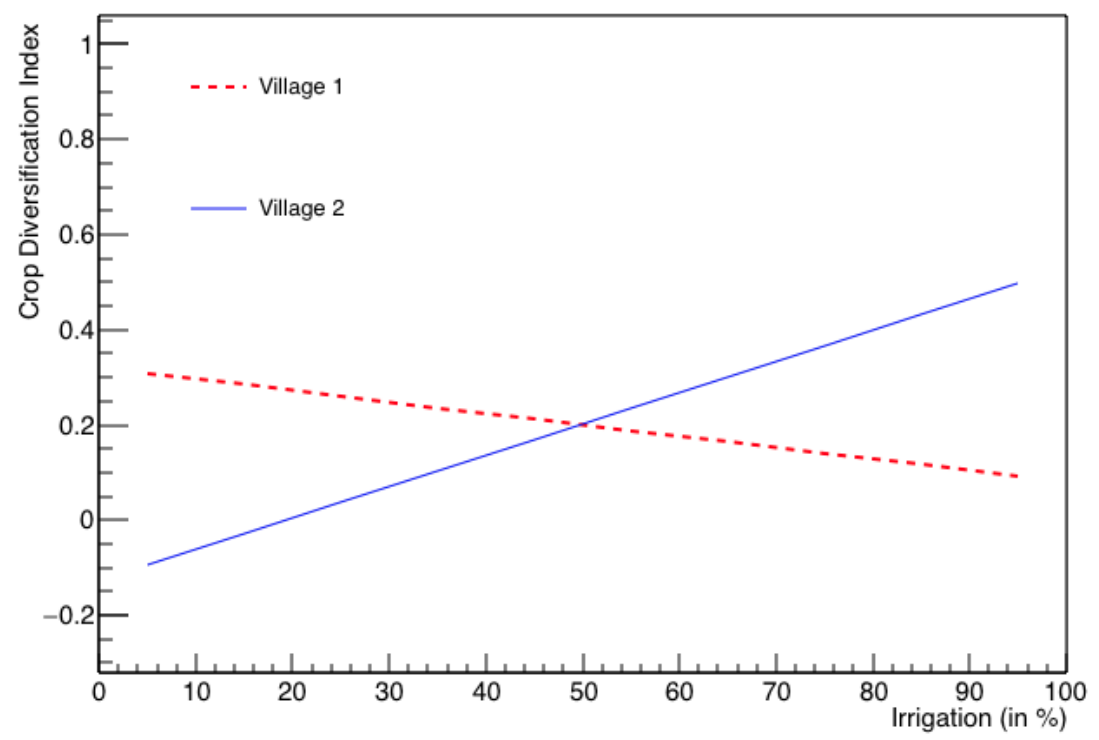

Figure 1: (Color online) the lines speak the impact of irrigation potential on crop diversification

are listed in Tab. 7. If we would plot this SLR result in a figure, it will give us the following result as shown in Fig. 1.

In Fig. 1 we can see the straight lines states the regression results of 2 sample villages. In Sindhigam there is a negative impact of irrigation or we say the irrigation potential has no such impact on crop diversification as it slopes downwards 0.4 to almost zero. But in Putra there is positive trend observed in between irrigation potential and crop diversification which ranges from -0.1 to around 0.5. As in Sindhigam though there is irrigation facility in 2008-09 but the farmers couldn't utilized the irrigation potential so this shows a negative diversification at the initial part of the figure.

\section{$5 \quad$ Findings and suggestions}

Crop diversification is the need of the day. We have studied the impact of irrigation on crop diversification. It can be concluded that though there is an impact of irrigation potential on crop diversification but it fluctuates and can be said that there are other factors responsible for crop diversification. Govt. should take steps for the awareness of crop diversification in these tribal regions through SHGs and the schemes must be effectively implemented in the area.

\section{References}

[1] Rao, P. P., Joshi, P. K., Kumar, S and Ganguly, K., (2008), Agricultural Diversification in Andhra Pradesh, India: Patterns, Determinants and Implications, (Published jointly with the International Food Policy Research. 
[2] Impact of crop diversification on tribal farmer's income: A case study from Eastern ghats of India by Sadasiba Tripathy, Dr. Sandhyarani Das, arXiv:2010.10208 [econ.GN] https: //arxiv.org/abs/2010.10208

[3] Pratap Singh Birthal, P. K. Joshi, Devesh Roy, Amit Thorat (2007), Diversification in Indian agriculture towards high-value crops The role of smallholders, International Food Policy Research Institute (IFPRI) Discussion Paper 00727

[4] Nayak and Kumar 2019: Nayak C. and Kumar C R. (2019) Crop diversification in Odisha: an analysis based on panel data. Agricultural Economics Research Review 2019, 32 (1), pg.no. $67-8010.5958 / 0974-0279.2019 .00006 .5$

[5] Climate change and its impact on diversification of agriculture, by Sadasiba Tripathy and Sandhya Rani Das; JRIM trust for research and innovation, Balasore, April-June 2019, Vol V, Issue II, pages 29-34 http://www.jrim.net/pdfs/vol5/issue2/article03.pdf

[6] Padhi S.R., 2011 The Incredible Cultural Heritage of Gadaba Tribe of Koraput District , Orissa Review, page no: 66-72 http: //magazines.odisha.gov.in/Orissareview/2011/Feb-Mar/engpdf/67-73.pdf

[7] Census of India 2011; INSTRUCTION MANUAL FOR HOUSELISTING AND HOUSING CENSUS

[8] Gibbs, J. and Martin W. (1962). "Index of Diversification": Used from Quantitative Techniques in Geography: An Introduction. R. Hammond and P .S. McGullagh, Clarendon Press, Oxford. P. 21.

[9] Tripathy, Sadasiba (2020), "crop data koraput 2008-2018", Mendeley Data, V1, doi: 10.17632/772swd9nws.1 http://dx.doi.org/10.17632/772swd9nws. 1 